\title{
Village forums or development councils: People's participation in decision-making in rural West Bengal, India
}

\section{Commonwealth Journal of Local Governance}

Special Issue March 2010:

Commonwealth Local Government Conference

Freeport, Bahamas, May 2009

http://epress.lib.uts.edu.au/ojs/index.php/cjlg

\section{Raghabendra Chattopadhyay, Bhaskar Chakrabarti, ${ }^{1}$ Suman Nath \\ Indian Institute of Management, Calcutta}
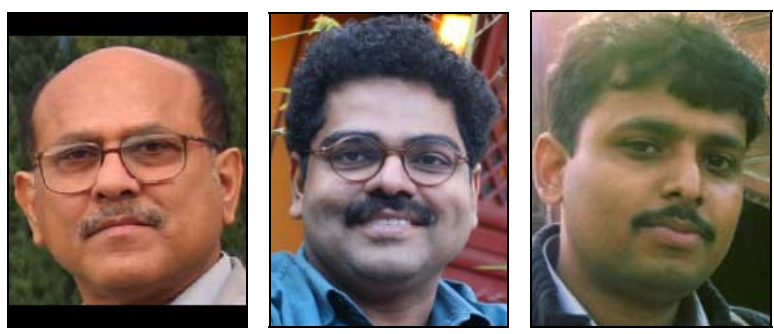

\section{Abstract}

The policy shift towards decentralisation promises important social change in rural India, providing as it does a three-tier system of local self-governments, the Panchayats: at the village level, the district level, and an intermediate level between the two, called the Block Panchayat. There is evidence of far-reaching social change in rural West Bengal, a state in eastern India, after the Left Front government came into power, particularly because of revitalisation of the three-tier Panchayat system. The initial years of Left Front rule saw the village poor enthusiastically attending Panchayat meetings and taking part in decision-making at the village council, the Gram Sabha, the general body of villagers of voting age covering 10-12 villages, and the Gram Sansad, the forum of local democracy at the ward level. However, today, relatively few people in the villages are taking part in government-sponsored initiatives. Panchayat meetings are scarcely attended and almost always exclude certain classes and members of the community. In order to combat the problem, the Government of West Bengal has recently tried to further devolve the power and responsibilities of local government and has established Gram Unnayan Samiti (GUSs) or Village Development Councils, consisting of political members from both

\footnotetext{
${ }^{1}$ Author for correspondence.
} 
elected and the opposition parties and certain nominated members. The GUSs are supposed to bring in more participation at the grassroots level. In this paper, we study the formal policies regarding decentralisation and people's participation in West Bengal, and analyse the dynamics of political processes regarding decision-making at operational level after the introduction of GUS. We have analysed audio recordings of meetings of the Gram Sabhas and the dynamics of the newly formed GUSs to uncover the actual rate of people's participation, actual meeting procedures and reasons behind people's reluctance to participate. We argue that solutions lie in having a strong third-tier in order to address issues of lack of transparency and accountability in decision-making, and make recommendations as to how that might be achieved. ${ }^{2}$

Keywords: People's participation in decision-making, Local politics, Village development councils.

\section{Introduction}

Rural local governments in West Bengal, the Panchayats, have two related aims: a) decentralisation of power, and b) encouraging people's participation in development and decision-making. The Village Panchayat (Gram Panchayat or GP) has at least one member from each village, and covers $10-12$ villages. Sometimes, if a village is too big then more than one member represents it. There is then a block-level Panchayat Samiti covering all the Village Panchayats in a particular block (area). This is the intermediate level of the Panchayati system between the villages and the district. Above the Samiti, there is a Zila Parishad, or the district-level Panchayat body representing all Panchayat Samitis in a district. A voter elects his or her representative to all three tiers.

The Gram Sabha is the general body of villagers of voting age operating alongside the Village Panchayat. It is the decision-making body at the local level. There is another forum of local democracy at the ward level: the Gram Sansad. Voters are members of both the Gram Sabha and the Gram Sansad. The Gram Sabha is expected to meet at least once every year to discuss issues related to the overall development of the

\footnotetext{
${ }^{2}$ An earlier version of this paper was presented at the Research Colloquium of the Commonwealth Local Government Conference, Bahamas, 10-14 May 2009. The authors thank participants at the Colloquium for the discussion, anonymous reviewers for their valuable comments, and Soumyasubhra Guha for copyediting.
} 
villages, while the Sansad is supposed to meet twice. It is expected that local participation will be channelled through regular meetings of the Gram Sabha and the Sansad. It is mandatory to notify all people in the village above eighteen years of age at least one week before these meetings. Ten percent of the villagers need to be present to make a quorum. If these meetings are not held, the activities of the Panchayat are not approved and a higher authority may suspend the Panchayat. Gram Sabha meetings provide an opportunity for common people to:

- Discuss, approve, disapprove, and prioritise future plans of action according to their felt needs

- Identify and include people-in-need for poverty alleviation projects

- Perform social audits (Government of India on Panchayati Raj, 2009).

These are tasks to be carried out by through voluntary participation to enable people to make decisions about their own lives and resources. Gram Sabha meetings provide the place to exercise the power that rests in individual voices. The Government of India emphasises the importance of a strong Gram Sabha:

The 73rd amendment thus envisages the Gram Sabha as a foundation of the Panchayat Raj system. "Gram Sabha" means a body consisting of persons registered in the electoral rolls, comprised within the area of Panchayat at the village level. In the Panchayat Raj system Gram Sabha is the only permanent unit. Mukhiyas [heads] and other members of Panchayat continue for 5 years only from the date appointed for the first meeting, but the villagers do not change.

Empowerment of Gram Sabha means strengthening of the Panchayat Raj Institution (PRIs). Success or failure of this system depends upon the strength of the Gram Sabha. (Planning Commission, Government of India on Panchayati Raj, 2009, 91).

As well as acknowledging Gram Sabha as the foundation of Panchayati Raj system, the Government of West Bengal has made two further provisions (Planning Commission, 2009). In 1994 in the light of $73^{\text {rd }}$ amendment to the Indian Constitution, Gram Sabhas have been empowered to form Gram Sansad for planning and implementation, and in 2003 through a revision of the local government Act of West Bengal, Gram Sansad were given authority to form one Gram Unnayan Samiti (village development council) for local planning and implementation in each area (Panchayat and Rural Development Department, GoWB). These initiatives are 
expected to encourage people's participation in the development process, and make local governments more accountable to the common people.

In the research for this paper we have used two methods for studying the dynamics of meetings of Gram Sabha and Gram Unnayan Samiti. First, we carried out phenomenological transcript analysis of Gram Sabha meetings to explore the nature of the meetings. Second, we analysed data from ethnographic fieldwork in nineteen wards having Gram Unnayan Samitis in the East Midnapore district, in order to explore local issues related to the formation and activities of the Gram Unnayan Samitis, and the level of people's participation. In this way we sought to capture the larger domains of politicisation and people's apparent reluctance to participate. We find that Gram Sabha meetings and Gram Unnayan Samitis (GUS), which are expected to function apolitically, have failed to fulfil their goals. People's participation at the Gram Sabha meetings is alarmingly low and their space suffers from unintended politicisation. The ethnographic study of issues related to GUS formation and activities has unmasked a detrimental political culture that underlies people's lack of interest. Explanations for the failure of these two democratic spaces are presented here with the argument that in a politicised state like West Bengal, where the Left Front government has been in power for more than 30 years, there needs to be a strengthened third tier. Further devolution of power through the village development councils will not necessarily mean a better system.

\section{Methodology}

As noted above we used a mixed-method approach to address different contexts viz. Gram Sabha meetings and issues related to Gram Unnayan Samiti. The mixed-method was required to yield data that could uncover the essential dynamics of the two different contexts. We conducted audio recordings of the entire activities of $44 \mathrm{Gram}$ Sabha meetings in the Birbhum district over a period of one year - without intervening in the free flowing events. After completion of the recordings, written transcripts were generated from the audio files and the essence of the discussions analysed. This led to an understanding of the broader contextual nature of people's voices within the development discourse. Following Giorgi (1970) we have used phenomenology to describe the essence of the meetings. In doing so, we drew on the work of Devanish (2002) and Schweitzer (2002) who discuss the inductive analysis of interview 
transcripts inspired by Giorgian phenomenological analysis. We have applied a relatively simple form of this analysis in three steps, which helped us generate essences that contextualise the discourses and map local issues within the larger context of people's participation in decision-making. The three steps were:

1. 'Thick description' of the meetings with minute details of the discussions, along with context references (see Geertz, 1973)

2. Coding, to identify themes of discussion and quantify themes

3. Integration of themes to discover the core issues in Gram Sabha meetings.

To study the effectiveness of the Gram Unnayan Samitis, ethnographic fieldwork was carried out in nineteen wards (that make up the Gram Unnayan Samiti) in the East Midnapore district. We interviewed and conducted group discussions with Panchayat officials, elected representatives and villagers. In each of the nineteen sansads there was one group discussion followed by individual interviews with various stakeholders. We did not restrict our fieldwork to any defined sample of the number of people to be interacted with, because the aim of studying the Gram Unnayan Samitis was to expose the nature of the issues at grassroots level that related to their formation and functioning.

\section{Context of West Bengal}

The level of popular participation in community affairs is certainly one measure of the quality of democracy at the local level. One could conclude that the more people participate in decision-making, the more democratic is the system of the government (Parry and Moyser, 1984). However, effective local democracy requires not only participation, but also that people's suggestions are reflected in policy outcomes (Saward, 1994). Even extensive participation may yet fail to produce a decision outcome that is supported by the majority or (ideally) all of the involved stakeholders (Satterfield, [article under review]). One of the dangers of decentralisation is that it may create 'pseudo-participation' and actually further empower local elites. For instance, during budget decision-making concerning water projects, each competing group could become defensive in terms of its own short-run goals instead of focusing on what is best for all (Rhoades 1999, p.339). Bias in the distribution of benefits from rural development could also derive from the fact that "a (political) regime might 
depend for its political support” from a certain class in the rural areas, and hence reward them (Blair, 2000).

As Bardhan and Mookherjee argue, problems derive from "weaknesses in the functioning of a fair electoral process at the local level, lower levels of political awareness of the poor, and the tendency for wealthier groups to form special interest groups" (Bardhan and Mookherjee 2000, 34-35). However, by reducing the cohesiveness of interest groups at the local level, and raising voter awareness and political competition, decentralization could be a beneficial process (Bardhan and Mookherjee 1999, 25-30). But they warn that in districts of high inequality and poverty local institutions will be vulnerable to 'capture', either by political leaders or by local elites:

Economic corruption in a centralised system then tends to be replaced by political corruption (in the form of diversion of services to local elites), despite the fact that agents in either system behave in a self-interested fashion. (Bardhan and Mookherjee 2000, 7).

Local people thus become consigned to a limited set of roles and relations with regard to the use of resources, and little autonomy is created. Ajay Mehta, in his study of two villages in southern Rajasthan in India, stresses the political processes within the Panchayat that strengthen those who already have the power to "control and co-opt the poor to serve their interests” (Mehta 2000,16). In a study of the Indian state of Kerala, the authors state: "When a party dominates a Panchayat, it tends to reward its sympathizers exclusively,” (Platteau and Gaspart 2003, 1697) although this might ultimately backfire in the Panchayat election. In West Bengal, where the Left Front coalition government with Communist Party of India (CPI-M, henceforth CPM) as the dominant party has been in power for 32 years, participation in decision-making is a complex dynamic process located across various levels of politics. Local management activity is influenced by factors outside the village, where political dynamics, external support and networking, as well as accountability mechanisms between political actors guide the decision-making process (Chakrabarti 2004). There seems to be a large difference between the formal arrangements of decentralisation aimed at increasing people's participation in decision-making, and what is actually happening in West Bengal. The present process, it seems, only aggravates the improper distribution of resources. Satadal Dasgupta (2001) argues that there has been polarisation of rural 
West Bengal into two major groups, the landed and the landless, and it is the class identities of these groups that leads to political conflict. Harry Blair's (2000) work shows the bias in distribution of benefits because the ruling party wanted to maintain the loyalty of certain farmers and rewarded only them. Bhattacharya (1999) shows how the peasant society is 'captured' by local party members, leading to skewed decision-making. The village poor who now abstain from going to the Gram Sabha meetings no longer see grassroots participation as an important avenue to control their own resources.

\section{Findings from Gram Sabha meetings}

Detailed analysis of transcripts brings out the following indicators of effectiveness of the Gram Sabha meetings:

\section{People's participation}

As Gram Sabha meetings are for common people, their success largely depends upon people's participation. Data regarding people's participation in the Gram Sabhas during 2003-04 show that on average 1120 heads are required for attaining a quorum but the average participation of people is only 137. Kirnahar Village Panchayat recorded the lowest attendance, where the head of the local government was the only person present. He read out the yearly budget statement and then called off the meeting. The highest attendance was found in Kushmore, where 1427 heads were present, but this was still four short of quorum. The gap between quorum and people present shows a serious lack of people's participation and raises the question: how could the meetings continue? During our fieldwork we found that people's signatures were collected at their houses before or after the Sabhas, producing a false record of quorum attainment. Even so, 16 out of 43 Village Panchayats postponed Sabhas and are desperate to complete their responsibility to hold meetings

\section{Meeting duration}

The idea of Gram Sabha is not only to bring people together but also to discuss local development plans in detail so that people's voices are reflected in both planning and implementation. The time it takes is important because plan approval, review of budget statements and social auditing are time-consuming tasks. However, our studied Gram Sabhas took only on average 38 minutes to complete the meeting procedures. 
The shortest meeting of only 5 minutes took place in Karidya Village, whilst the longest was 112 minutes taken by Md. Bazar Village. We do not argue that the quality of meetings directly depends on the time taken, but the average length of Gram Sabhas appears insufficient to complete the expected tasks.

\section{Nature of issues dealt with in Gram Sabha meetings}

After initial coding of the recorded transcripts we have identified the various issues discussed and calculated the percentage of Gram Sabha meetings that included them (Figure 1.) Figure 1 shows that most Gram Sabha meetings are confined to the discussion of budget and income-expenditure statements. Discussion of future plans has taken place in 54 per cent, and plan prioritisation in only 10 per cent. More than 20 per cent of the Village Panchayats have used Gram Sabhas to deliver long speeches on success stories of the Panchayats and particular political parties. In about 10 per cent of the Gram Sabhas, local influential party workers have delivered speeches. It seems that most of the Gram Sabhas have failed to incorporate people's voices in planning and decision making processes. The more alarming finding is the political interference in meeting procedures. 


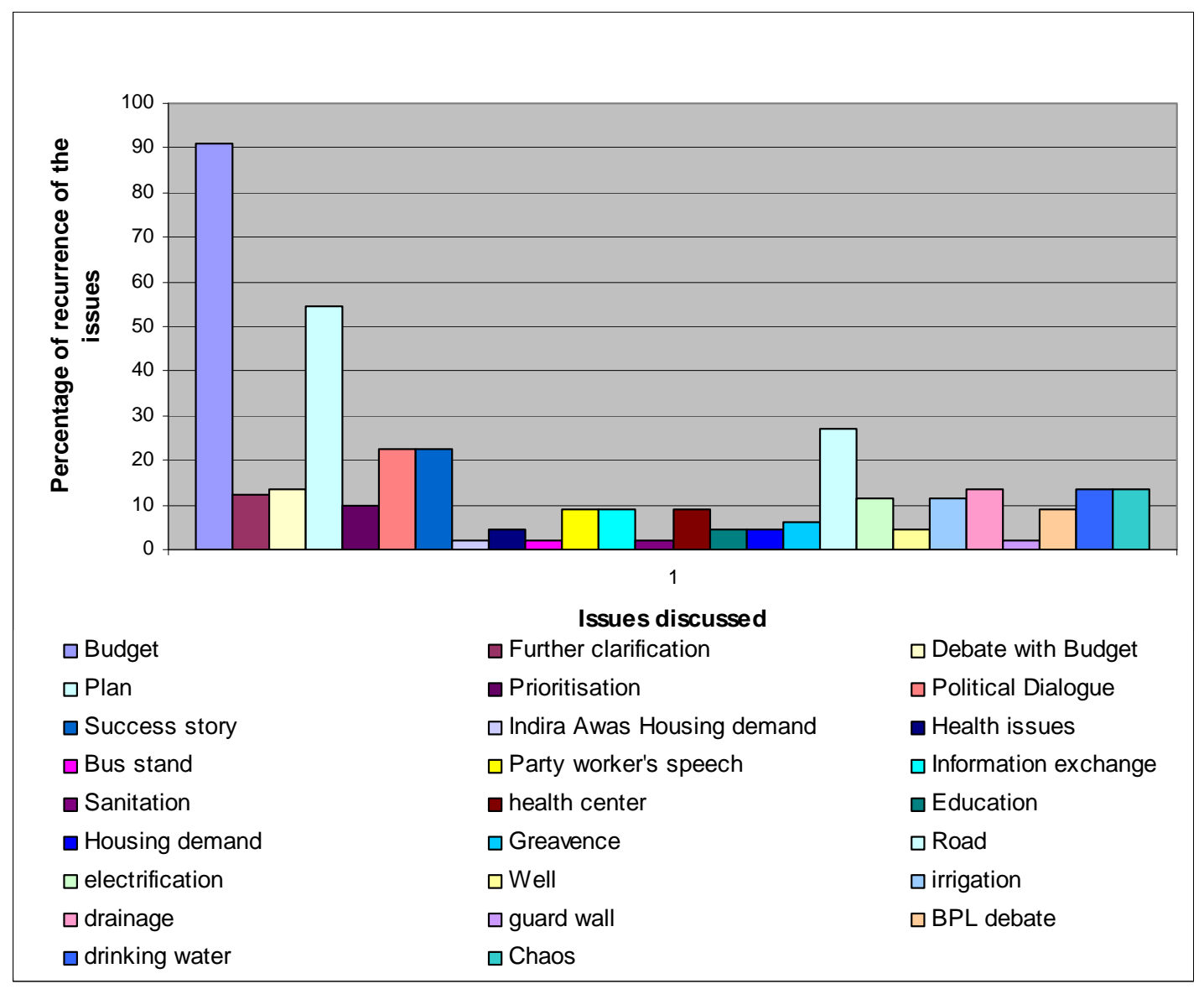

Figure 1. Frequency of issues discussed across Gram Sabhas

\section{The interactions}

Using the three-step transcript analysis, several domains of discussion reflect the nature of discussions in the Gram Sabhas. The agenda of planning and needs-based prioritisation require interaction between stakeholders. Our transcript analysis shows that interaction between representatives, official members and villagers has been limited to 27 per cent of the studied Gram Sabhas. Furthermore, only 9 per cent (4 out of 44) of the Gram Sabhas have free flowing conversation and long debates over planning and budget statements. In five Gram Sabhas (11 per cent) people demanded further clarification of the statement of budget and income-expenditure. Among these five meetings, in three cases a debate was forcefully halted by elected representatives. A chaotic reaction was noted in 13 per cent of the Gram Sabhas where no constructive discussion took place. If we add people's active participation (27 per cent) and indistinct chaos (13 per cent), we can argue that in about 40 per cent of the Gram Sabhas, people have actively engaged in meeting procedures. However, the evidence 
suggests their voices remained unheard except in two cases. Thus there is a failure of the participatory agenda of Gram Sabhas. It is important to search for the reasons for this failure, which requires a closer look at the other themes discussed at the Gram Sabha meetings. In about 91 per cent of the Gram Sabhas studied, budgets and income-expenditure statements were presented in a monologue without any discussion. Apart from the 9 per cent of the Gram Sabhas, where good interaction was noted, in another 9 per cent village members (of the local government) asked the people for their comments, and in about 7 per cent the people formally approved the budget statement. For example in Chowhatta, the people approved the budget in a very formal way after being asked by the head of the Village Panchayat:

Female voice: The income-expenditure statement which the Head has laid down, on behalf of the women we approve it.

Male voice: The income-expenditure statement that the Head has laid down, we observe it to be true and approve it.

Female voice: The income-expenditure statement that the Head Sir spoke about, we approve it Male voice: The income-expenditure that our head Sir read out, we approve it.

(Transcript of recording, Chowhatta, Birbhum, 8 January 2003).

This formal way of giving approval indicates people's passiveness and reluctance to enter into discussion, and it is worth recalling that even this minimum space to raise people's voices is provided only in 9 per cent of cases. Another important agenda of Gram Sabha meetings is constructive discussion on planning and decision-making. To generate such a discussion, a careful presentation of the future plan is necessary, however, we found that in only 54.5 percent of the Gram Sabhas were planning and project proposals read. Further discussion of projects was alarmingly low.

\section{Politicisation of Gram Sabha meetings}

Gram Sabhas are meant to be the common people's arena and, ideally, the nature of discussion and involvement of people in planning and decision-making should be impartial and apolitical. However, the transcript analysis revealed that in about 23 per cent of the Gram Sabhas a political speech was delivered. These discourses address three kinds of issues: the long history of success of the ruling party; blaming political differences between Block and Village Panchayats for failure; and comparative stories of success and failure where a changeover in the political party has taken place. It is 
important to see who delivers the speech because that reflects the person who embodies political power. In 16 per cent of Gram Sabhas, we found that the political leader from higher level, usually the Block or the District, is invited to deliver the speech. For example in Khoyrasole, a Local Committee member started his speech by mentioning the Left Front government's success:

Friends! The Panchayati Raj system has brought in radical changes in the rural socio-economic scene in West Bengal; the left ruled state in India has made all the difference...

(Transcript of recording from Khyarasole, Birbhum 31 December 2003)

Similarly in Chowhatta, the change in political scenario was emphasised:

In 1977 the political change that took place in West Bengal... the Left Front Government was elected by the people... Immediately after being elected they declared that they won't direct everything from the Writer's Building as was done previously and power would be in the hand of people.

(Transcript of recording from Chowhatta, Birbhum 8 January 2003)

In Haridaspur, a local political leader was invited to deliver a long speech which took away time from the people's discussion. In Dhakalbati a comparative account was presented to show the better performance by the newly formed board.

In the 25 years tenure of Left Front this is the first time in... that there is no allegation against the village Head. Last five year's progress has been excellent... We have worked beyond our expectation. There is no political disparity... everything was divided equally... previously, there was partiality, but our tenure has been impartial...

(Transcript of recording from Dhakalbati, Birbhum 3 January 2003).

In Mallikpur, Siuri the focus of the meeting was to blame the Panchayat Samiti at the upper tier, the Block:

\footnotetext{
...there is no development inputs by the current Panchayat Samiti. 'Our' previous Panchayat Samiti was engaged in running literacy centre. It is true that the current Panchayat Samiti is also continuing this programme, but the momentum is lost... Moreover in the estimated budget, there is no allocation for our region... (Transcript of recording from Malikapur GP, Birbhum $7^{t}$ January 2003)
}

The presence of political leaders from outside the area was noted in 86 percent cases and in each, a special mention of the visitors was made by the Village Panchayat heads. In many areas these Gram Sabhas have thus become a new forum to revitalise political agendas. 


\section{Voice suppression}

Being a space for common people's activities, Gram Sabhas should rely on the power of individual voices. The success of active participation depends on how far people's aggregated voices get reflected in discussion of development issues in the locality. However, transcript analysis indicates that in 39 per cent cases people's voices are suppressed and/or ignored during discussions. For example, in Mallikpur, Suri, female voices are at first suppressed and then simply ignored.

Female: I am from Mulipara of Nudur area. I wish to let you know that we are extremely poor widows. We ought to depend on others...

Assistant from the Panchayat: We are here to listen to area problems, tell us about your area, not about yourself.

Female: I have lost my husband too. I am in serious crisis. It is about us, the widows living in extreme poverty.

Female: My husband has lost both of his legs. I need help to sustain. I request you to help me.

Female: I am a beggar with a handicapped son. Please do something for me. I have seen many people getting money, clothes, etc. I did not get anything.

Female: Muslimpara suffers from paucity of water. We do not have any pond or tubewell. Please do something.

Assistant: The woman coming from Nahodari spoke about the water scarcity too, the Head is also aware of this. It is known to us that you are new settlers beside the highway. We have noted down your demand.

(Transcript of recording from Malikapur GP, Birbhum 7 January 2003)

The conversation suggests that apart from the last request, which was already known to the Village Panchayat, others are ignored. Phenomenological transcript analysis thus uncovers two related issues: first, the failure of the participatory agenda due to people's reluctance to become engaged in discussion; and second, ignoring or suppressing people's voices. Since the number of participants is alarmingly low in the first place, any voice suppression will have a considerable additional adverse effect on the participatory agenda. Thus, lack of opportunity for people to raise their voices, the formalised approval process for proposals put forward by the Panchayat, and meeting politicisation are all possible reasons for the reluctance of people to participate. It is for these reasons that the local government department has tried to promote Village Development Councils, the Gram Unnayan Samitis.

\section{Village development councils: Organised effort to empower people?}

A brief glance at the organisational structure of Gram Unnayan Samiti (GUS) reflects an intention to promote people's participation from all sectors, including the different political parties. In this section, we analyse the functioning of a council in East 
Midnapore district and explore whether or not it has been successful in addressing the problem of participation visible at Gram Sabhas. In the district the GUS consists of a nominee of local women, an opposition member (the candidate who lost the village level election by the smallest margin of votes), self-help group members, retired teachers, and former government employees whose political leaning (at least ideally) is not clear. Formation of the GUS takes place through a pre-announced and well communicated meeting chaired by the head of the Village Panchayat, where the local government secretary presides. Villagers are supposed to propose, support or oppose the names of the people from the region to become members of the GUS. This structure of the GUS is supposed to increase involvement of local people in bottom-up planning, and enhance economic development and social justice through an apolitical body. The council is assisted through training in: preparing a resource database, identifying existing problems (and making effective plans to cope with them), and the implementation of existing plans. In six backward districts, including East Midnapore, as determined by a District Development Index, the UK Department for International Development (DFID) has sponsored a programme of Strengthening Rural Decentralisation (SRD), which provides special support for continuation of GUS activities. $^{3}$

\section{Politicisation of the GUS}

Our study shows that the policy of forming the GUS as an apolitical body of villagers is confronted with problems deep-rooted in the nature of village politics and polarisation in the East Midnapore district. Village factional politics and recent changes in the political scenario have only added to the difficulties. Soon after the Panchayat elections, the different political parties started mobilising people to gain support and secure a strong presence on the GUS, which is commonly misunderstood as a space for exercising economic and political control. For this study, we interviewed 81 GUS members and asked about peoples' interests (not their self-interest) in joining the GUS. Most viewed the organisation in opportunistic terms including one or more of the following:

- Economic gain (73 out of 81 GUS members).

- Space to strengthen an existing political base (69 out of 81)

\footnotetext{
${ }^{3}$ See http://www.dfid.gov.uk/Documents/publications/transforming-rural-livelihoods-india.pdf
} 
- Space to exercise power as an individual and as a member of a specific political party (33 out of 81 GUS members).

Every village reported the phenomenon of 'panel placement' by party members for the GUS. When the local government secretary (ie. the presiding officer) sought nominees for the reserved and unreserved positions, two panels were put forward by the ruling and opposition parties respectively. Their supporters then aligned themselves accordingly to make the voting process easier. This process indicates that the GUS is becoming another political entity and not a common people's arena. Fourteen out of nineteen village areas studied formed their GUS in this way. Four GUSs are yet to be formed as endeavours to do so failed due to the low rate of participation and political conflict. In another case, the outcome is subject to a court ruling and the GUS is inactive. It is also noteworthy that because of these problems, the Government of West Bengal is not imposing the mandatory formation of GUSs.

\section{Political conflicts: the GUS battleground}

As noted above, the evidence indicates that a number of GUSs have become politicised before, during and after their formation, and effectively used as a tool to appropriate political interests. Controlling the GUS seems to have become a preoccupation of the political parties. In two regions, villagers were threatened by the defeated party not to attend the Gram Sansad meeting where people were to be nominated for appointment to the GUS. In these two Gram Sansads, a quorum was not attained on the first day and the meeting adjourned. On the next day, the winning party urged villagers to attend and assured their safety and asked for their vote. This resulted in a one-party GUS. In another case, the defeated party brought supporters from outside the village to increase the number of votes. The winning party reciprocated and hence the place became a 'battlefield' between the two groups and the meeting was cancelled. Several months later the 'blame-game' around these events is continuing. The question of 'who did it first' became more important than the formation of the GUS. In another village, political conflict went so far that the meeting had to be adjourned and police called to escort local government officials to safety. The villagers argue:

It is hampering our daily lives - after that meeting we all know who is from which side! I know who is with me and who is against me. I am afraid about 
my security. Who will save us from the party mafias? After that meeting either you are with me or you are against me. No one can stay in between. If you choose not to go to meeting you are against the both. (Villager, Kamarda GP area, East Midnapore recorded 10 December 2008)

A new level of conflict was attained in another case, mentioned earlier, where the GUS was established but then its legitimacy challenged in the district court. In the said village, nominations for the GUS were dominated by the party that lost the Panchayat election, but which had previously ruled the ward for more than two decades. The winning party challenged the legitimacy of the GUS on the grounds that villagers had voted in fear, given the open voting process. These situations have divided villagers into two groups as their political allegiance becomes evident. Many strong local, friendship and kinship ties have broken down after the formation of a GUS. Sadly, this has created a new hierarchical division in village society and a tension-filled environment.

\section{Motivation of GUS members}

We enquired about people's motivation to participate in the GUS, and present the results in Table 1:

\begin{tabular}{l|c|c|}
\hline Motivation & Number & Percentage \\
\hline Dissatisfaction from previous work & 3 & 3.7 \\
\hline Helping others & 14 & 17.2 \\
\hline Party pressure & 35 & 43.2 \\
\hline Village pressure & 10 & 12.4 \\
\hline Both party and village pressure & 2 & 2.5 \\
\hline Seen as a new opportunity for employment & 11 & 13.6 \\
\hline Feeling lonely after retirement & 6 & 7.4 \\
\hline \multicolumn{2}{|l|}{81} & 100 \\
\hline TOTAL & 81 \\
\hline
\end{tabular}

The table shows that party pressure plays a major role. Most members agree that their entry to politics is through the GUS, which is seen a step to learn and then get involved with the Village Panchayat. A threefold incentive for working voluntarily as a GUS member emerges: power, money and prestige. 
[The] Government never makes people work without pay! We still feel that by satisfying them, we will get something in return.

When we see people asking and discussing their demands with us, showing respect, it makes us happy.

(Members of GUS, Basantapur GP, East Midnapore recorded 11 December 2008)

\section{Impacts on programmes}

The formation of a GUS is the first step in continuing existing programmes and initiating new ones however political conflict clearly creates obstacles in programme implementation. There are instances, for example, of political opponents denying access to land needed to create work under the recently implemented rural employment guarantee schemes. In another case, the social forestry programme was severely affected by the destructive attitude of opponents who uprooted saplings and destroyed the protective fences around the plants. Elsewhere, almost twice as many labourers as were really needed were given work on a rural employment project because both the dominant and opposition groups within the GUS sent their respective supporters.

\section{Core findings from the two contexts}

The study reveals numerous localised issues that reflect two larger domains: first, the unintended politicisation of the democratic space; and second, people's passiveness. In the following sections, we discuss these core issues, their dimensions and their impact on local government.

\section{Unintended politicisation of the democratic space}

The primary issue related to the failure of the participatory agendas of both Gram Sabhas and GUSs is unintended politicisation. In Gram Sabha meetings, political agendas are created and presented through delivered speeches, while in case of the GUS, politicisation starts from the period of GUS formation as it is viewed as a space to exercise political control. In both cases the formal mechanism has been subverted by informal party political activity. The political process of decision-making is of course important and could play a productive role if large-scale people's participation is ensured - the original agenda of the Panchayat system. However, the poor rate of participation in Gram Sabhas, and problems with GUS formation reveal a detrimental political atmosphere in the villages. A significant factor is people's fear of being 
'tagged' politically due to the open voting system. The situation creates problems in three ways: it hinders large-scale and equitable participation in planning and implementation processes; it constrains the operation of development programmes; and, it disengages people from politics and decision-making. This creates scope for opportunistic behaviour and corruption, as the political parties lose accountability to the common people.

That [politics] is not my place. I know I have voting rights, I exercise that right. That does not make any difference. We have to choose from possible alternatives! 'Whoever rides the chair, becomes the king!' the situation remains the same. Politics means threat... I don't want development, I want a peaceful life.

(Voice of a villager in Chaitanyapur GP, East Midnapore, recorded 12 December 2008).

Although issues of politicisation arise in both the Gram Sabha and the GUS, the degree of impact on people varies. The problems outlined with respect to Gram Sabha meetings are essentially procedural and 'simply' diminish their value. On the other hand, conflicts surrounding the Gram Unnayan Samiti reveal an organised effort by political parties that reflects the greater opportunity to exercise power. As a result, people are pressurised to participate in the open voting system to support one of the two panels because in such settings 'numbers' matter to the parties. The Gram Sabha carries no such incentives for the political parties and little pressure is placed on people, even though some political intervention is notable. These contrasting situations show that the core political incentive at work is to 'steer benefits'. People are left with no option but to choose from alternatives that are 'structured' by the different political parties.

\section{People's passiveness}

Political interference in democratic space is evidenced in both contexts, but people are often found to remain passive and detached even though this detachment is not in their best interests. Why do people remain passive? It is largely a result of the failure of collective mobilisation. A situation in which 'facts' speak out unmistakably for or against a definite course of action. Georg Lukács' argument is worth remembering here: "A situation in which 'facts' speak out unmistakably for or against a definite course of action has never existed, and neither can or will exist” (Lukác 1972, 23). 
Therefore there is little possibility of change until some concerted effort is made to work towards organising people against their passiveness.

\section{Conclusion}

Our study supports previous work by Bardhan and Mukherjee (1999) and Satadal Dasgupta (2001) about the politicisation of decision-making in rural West Bengal, reflecting among other things the underlying divisions in village society, the "controlling power of knowledge" (Sim 2001), and the path dependency that flows from long-term control by one party and which makes local institutions selfreinforcing (Pierson 2000).

This paper has documented problems associated with a lack of communication, understanding (and hence people's involvement), the nature of village politics, and open voting procedures. In particular, the aims of GUS have never been communicated properly to local people who do not realise the benefit of having such a body within the village. Political parties have taken advantage of this lack of awareness and see the GUS as an alternative power base, especially for those who lose control of or positions in the Panchayats. Political polarisation has deepened divisions in village life: many common people currently avoid political participation, whilst others are supporters or members of different political parties who are used as the 'medium' for approving decisions and exercising control. A strategy is needed to restore the political peace and encourage people's participation in the development process.

Tactics such as the devolution of power and encouragement of people's participation do not lead automatically to a better system of local government. Increasing the effectiveness of the system requires strengthening of the administrative arm of Panchayats, and/or, large scale and better informed participation by the common people, which in turn calls for a concerted effort. One option may be to establish a support structure that enables the local governments to engage more effectively at the grassroots level. This might consist of personnel responsible for:

- Creating awareness about participation amongst the villagers 
- Searching for people from the village with leadership skills by involving party workers (who are not elected representatives), elected representatives and common people

- Empowering others to act and remove barriers through communication in a culturally sensitive way

- Encouraging people to set achievable short-term goals so that more people feel interested

- Help in a monitoring and evaluation process so that people can see the benefits flowing to their localities.

Finally, it is important to understand that change through these endeavours will take time. A major problem with policies for development and participation is that they are initiated rapidly, frequently without proper social infrastructure. As a result, they fail and sometimes create long-term detrimental effects. It must be appreciated that these initiatives are aimed at cultural change - to make people active, participatory and less path-dependent in a society with a long legacy of division and polarisation. The endeavour should be slow and steady and should build on current arrangements in a culturally sensitive way to bring about long-term and sustainable change towards collective benefits.

\section{References:}

Bardhan, P. and Mookherjee, D. 2000, 'Decentralizing Anti-Poverty Program Delivery in Developing Countries’, Journal of Public Economics. Viewed 20 March <http://globetrotter.berkeley.edu/macarthur/inequality/papers/\#Bardhan>

Bardhan, P. and Mookherjee, D. 1999, Relative Capture of Local and Central Governments: An Essay in the Political Economy of Decentralization (Working Paper), Center for International and Development Economics Research, University of California, Berkeley. Viewed 20 March 2009 <http://globetrotter.berkeley.edu/macarthur/inequality/papers/cap31.pdf>

Bhattacharya, D. 1999, 'Politics of Middleness: The Changing Character of the Communist Party of India (Marxist) in Rural West Bengal (1977-90)’ in Ben Rogaly (ed.), Sonar Bangla: Agricultural Growth and Agrarian Change in West Bengal and Bangladesh, Sage: New Delhi.

Blair, H. W. 2000, 'Participation and Accountability at the Periphery: Democratic Local Governance in Six Countries’ World Development, vol. 28, no. 1, pp. 21-39.

Chakrabarti, B. 2004, 'Participation at the Crossroads', unpublished PhD Thesis, University of British Columbia, Vancouver, BC.

Dasgupta, S. 2001, 'Caste, Class and Political Conflict: Perceptions of Social Change in West Bengal Villages’, Panchanan Mitra Lecture delivered on 6 July 2001 at the Asiatic Society, Kolkata, in Journal of Asiatic Society, XLIII, 1, pp. 48-76. 
Devenish, S. 2002, 'An applied method for undertaking phenomenological explication of interview transcripts’, Indo-Pacific Journal of Phenomenology, vol. 2, no. 1, pp. 1-20.

Department for International Development, 'Transforming rural livelihoods', viewed February $2010<$ http://www.dfid.gov.uk/Documents/publications/transforming-rural-livelihoodsindia.pdf $>$

Geertz, C. 1973, 'Thick Description: Toward an Interpretive Theory of Culture’ in The Interpretation of Cultures: Selected Essays. New York: Basic Books.

Giorgi, A. 1994, 'A phenomenological perspective on certain qualitative research methods', Journal of Phenomenological Psychology, vol. 25, no. 2, pp. 190-220.

Government of West Bengal 2006, Panchayat and Rural Development Department, Gram Unnayan Samitir hatboi. (In Bengali, Handbook of GUS). Kolkata: P\&RD.

Government of Rajasthan, Rural Development and Panchayati Raj Department, 'Chapter IIA Gram Sabha’, viewed 15 May, 2009 <http://www.rajpanchayat.gov.in/index english.htm>

Giorgi, A., Fischer, C. and Murray, E. 1975, ‘An application of phenomenological method in psychology’ in A. Giorgi, C. Fischer \& E. Murray (eds.) Duquesne studies in phenomenological psychology, vol. 2, Duquesne University Press, Pittsburgh.

Giorgi, A. 1970, Psychology as a human science: A phenomenologically based approach, New York: Harper and Row.

Lukács, G. 1972, History and class consciousness: Dtudies in Marxist dialectics. (Trans. Rodney Livingstone), MIT Press.

Mehta, A. 2000, 'The Micro Politics of Participatory Projects: An Anatomy of Change in Two Villages', in Pauline E. Peters (ed.), Development Encounters: Sites of Participation and Knowledge, Harvard Institute for International Development, Cambridge, MA.

Parry, G. and Moyser, G. 1994, 'More Participation, More Democracy?’, In David Beetham (Ed.), Defining and Measuring Democracy. London: Sage

Pierson, P. 2000, 'Increasing Returns, Path Dependence, and the Study of Politics’. American Political Science Review, June.

Pierson, P. 2004, Politics in Time: Politics in Time: History, Institutions, and Social Analysis, Princeton University Press.

Planning Commission of India 'Objectives - Panchayat Raj Institutions: Gram Sabha'. Viewed 15 May, 2009 < $\underline{\text { http://planningcommission.nic.in/reports/sereport/ser/bihinter/st bihch11.pdf> }}$

Planning Commission of Idea, Report on PRI. Viewed 15 May, 2009 <http://planningcommission.nic.in/reports/sereport/ser/bihinter/st_bihch11.pdf>

Platteau, J-P and Gaspart, F. 2003, 'The Risk of Resource Misappropriation in CommunityDriven Development', World Development, vol. 31, no. 10.

Rhoades, R. E. 1999, 'The Participatory Multipurpose Watershed Project: Nature’s Salvation or Shumacher's Nightmare' in Rattan Lal (ed.), Integrated Watershed Management in the Global Ecosystem. New York: CRC Press.

Satterfield, T. 'Risk Communication, Fugitive Values, and the Problem of Tradeoffs: Diagnosing the Breakdown of Deliberative Processes', (under review) Science, Technology and Human Value, Sage.

Saward, M. 1994, 'Democratic Theory and Indices of Decentralization' in David Beetham (ed.), Defining and Measuring Democracy. London: Sage

Schweitzer, R. 2002, Editorial.[0] Indo-Pacific Journal of Phenomenology, vol. 2, no. 2, pp. 1-2.

Sim, S and Loon, B. V. 2001, Introducing critical theory. UK: Icon books. 